\title{
Peningkatan Prestasi Belajar dengan Pembelajaran Talking Stick dan Media Tangram
}

\author{
Wardatus Sholeha $^{1)}$, Rahaju ${ }^{2}$, Tri Candra Wulandari ${ }^{3)}$ \\ ${ }^{1,2,3)}$ Universitas Kanjuruhan Malang \\ Email:wsholihah7@gmail.com, ayurakoep@unikama.ac.id, fikri.chan@unikama.ac.id
}

\begin{abstract}
The aims of this study is to describe the steps of the talking stick learning model and tangram media which can improve learning achievement on quadrilateral in students of SMP Budi Mulia Pakisaji, Malang, Jawa Timur. This study is a classroom action research, the source of the data are 28 students of class VIIF. Data collection procedures used observation, written tests, and documentation. Data analysis includes data reduction, data presentation, and conclusions. Learning steps with a talking stick model and tangram media that can improve learning achievement is carried out with steps; the teacher divides students into heterogeneous groups, explains material using tangram media, the teacher asks each group to discuss completing the group worksheets, the teacher asks the group representatives to present the results of the discussion, the teacher prepares sticks and explains explaining the steps and rules of talking sticks, the teacher play music and give a stick to one of the students, then the stick is run in a relay. When the music stops, the student holding the stick must answer the question, if the aswers are correct, student will get a reward. The end of lessons, teacher with the student concluding the material learned. Learning outcomes using the talking stick model and tangram media showed an increase from the pre-action stage to cycle 1 by $27.97 \%$, while the increase from cycle 1 to cycle 2 was $11.78 \%$.
\end{abstract}

Keywords : talking stick, tangram, square, learning performance

\begin{abstract}
ABSTRAK
Penelitian ini bertujuan untuk mendeskripsikan langkah-langkah model pembelajaran talking stick dengan menggunakan media tangram yang dapat meningkatkan prestasi belajar pada materi segiempat pada siswa kelas VIIF SMP Budi Mulia Pakisaji, Malang, Jawa Timur. Penelitian ini merupakan penelitian tindakan kelas dengan sumber data adalah siswa kelas VIIF sebanyak 28 siswa. Prosedur pengumpulan data yang digunakan meliputi observasi, tes tulis, dan dokumentasi. Analisis data meliputi pereduksian data, penyajian data, dan penarikan kesimpulan. Pembelajaran dengan model talking stick dan media tangram yang dapat meningkatkan prestasi belajar dilaksanakan dengan langkah-langkah; guru membagi siswa menjadi beberapa kelompok yang heterogen, menjelaskan
\end{abstract}


materi menggunakan media tangram, guru meminta setiap kelompok berdiskusi menyelesaikan Lembar kerja kelompok, guru meminta perwakilan kelompok mempresentasikan hasil diskusi, guru menyiapkan tongkat/stick dan menjelaskan menjelaskan langkah-langkah dan aturan talking stick, guru memutar musik dan memberikan tongkat kepada salah satu siswa, kemudian tongkat dijalankan secara estafet, saat musik berhenti, siswa yang memegang tongkat harus menjawab soal, jika jawaban siswa benar, maka siswa akan mendapat hadiah, diakhir pelajaran guru bersama siswa menyimpulkan materi yang telah dipelajari. Hasil pembelajaran dengan model talking stick dan media tangram menunjukkan peningkatan dari tahap pratindakan ke siklus 1 sebesar 27,97\%, sedangkan peningkatan dari siklus 1 ke siklus 2 sebesar $11,78 \%$.

Kata Kunci : talking stick, tangram, segiempat, prestasi belajar.

\section{PENDAHULUAN}

Matematika merupakan salah satu mata pelajaran yang memiliki peranan penting bagi segala aspek kehidupan. Oleh karena itu, matematika diajarkan pada semua jenjang pendidikan, yaitu mulai dari SD, SMP, SMA, sampai Perguruan Tinggi. Alokasi waktu pelajaran matematika lebih banyak dari pada mata pelajaran lainnya. Alokasi waktu pelajaran matematika SMP yaitu 5 jam pelajaran per minggu dengan durasi 40 menit per jam pelajaran (Kemendikbud, 2013).

Akan tetapi, pada kenyataannya, matematika adalah mata pelajaran yang paling tidak disukai siswa. Hal ini ditunjukkan oleh sikap siswa yang sebagian besar kurang antusias mengikuti pelajaran. Hanya beberapa siswa yang bersedia menjawab pertanyaan guru. Selain itu, hampir semua siswa tidak berani mengemukakan hal yang sudah atau belum dipahami. Kondisi tersebut sesuai dengan yang terjadi di SMP Budi Mulia Pakisaji.

Kesulitan muncul karena guru kurang memberikan kesempatan siswa untuk terlibat dalam pembelajaran, sehingga mengakibatkan siswa tidak mencapai tingkat pemahaman yang ditargetkan (Hadi, 2017). Selain itu, dominasi guru dalam proses pembelajaran menjadi salah satu faktor yang menyebabkan siswa sulit untuk mempelajari materi pembelajaran sehingga siswa merasa bosan dan sulit memahami materi. Selain itu, minimnya penggunaan media pembelajaran juga dapat mempengaruhi siswa dalam menguasai pemahaman konsep. Media merupakan komponen sumber belajar atau wahana fisik yang memuat materi instruksional di lingkungan siswa, yang dapat merangsang siswa untuk belajar 
(Hamdani dalam (Fataturrohmah, Masykur, \& Suherman, 2017).

Salah satu solusi untuk mengatasi kesulitan dalam memahami materi matematika yaitu dengan menggunakan media pembelajaran yang dapat meningkatkan pemahaman siswa dan meningkatkan prestasi belajar siswa. Salah satu media yang dapat digunakan adalah tangram. Peneliti memilih media tangram dikarenakan siswa masih sangat sulit memahami materi bangun datar, hal ini berdasarkan hasil wawancara dengan guru matematika, media tangram belum pernah digunakan di SMP Budi Mulia khususnya pada pembelajaran bangun datar.

Peneliti menggunakan model pembelajaran talking stick, sedangkan agar pembelajaran lebih menarik, peneliti menggunakan media tangram. Talking stick adalah model pembelajaran yang melatih siswa untuk berani mengemukakan pendapat (Suprijono, 2011). Talking stick merupakan model pembelajaran yang berbantuan stick/tongkat sebagai penunjuk giliran menjawab pertanyaan guru. Kelompok atau siswa yang mendapat tongkat akan diberi pertanyaan dan harus dijawab. Demikian seterusnya sampai semua kelompok atau siswa mendapat tongkat. Penggunaan talking stick dapat meningkatkan minat siswa dalam mengerjakan soal dan membuat siswa berani mengemukakan pendapat. Media tangram dikembangkan sebagai variasi dalam pembelajaran, melatih pola pikir siswa, yang semula berpikir abstrak menjadi berpikir secara konkret dan menarik. Selain itu, penggunaan media tangram pada materi pokok unsur dan sifat bangun datar dapat meningkatkan hasil belajar matematika (Putra \& Wijiastuti, 2013). Sehingga, penelitian ini bertujuan untuk mendeskripsikan langkah-langkah model pembelajaran talking stick dan media tangram yang dapat meningkatkan prestasi belajar materi segiempat serta mendeskripsikan besarnya peningkatan prestasi belajar siswa kelas VIIF SMP Budi Mulia Pakisaji

\section{METODE PENELITIAN}

Penelitian ini menggunakan pendekatan kualitatif dengan jenis penelitian tindakan kelas. Oleh karena itu, peneliti bertindak sebagai intrumen utama yaitu perencana, pelaksana, pengumpul data, penganalisis data, dan penyusun laporan. Subjek penelitian adalah siswa kelas VIIF SMP Budi Mulia Pakisaji yang terdiri dari 28 siswa laki-laki. Pengumpulan data dilakukan dengan teknik observasi, tes, dan dokumentasi. Instrumen yang digunakan adalah lembar observasi, lembar kerja 
kelompok (LKK), dan soal tes tertulis. Data yang terkumpul dianalisis melalui tiga tahap, yaitu pereduksian data, penyajian data dan penarikan kesimpulan. Penentuan keberhasilan setiap siklus berdasarkan pada (a) ketepatan aktivitas guru dan siswa dengan kriteria keberhasilan minimal 70\%, (b) kriteria pencapaian prestasi belajar siswa secara klasikal dengan kriteria ketuntasan minimal memperoleh skor 75, paling sedikit mencapai $75 \%$ dari keseluruhan siswa.

\section{HASIL DAN PEMBAHASAN}

Sebelum melaksanakan siklus 1 peneliti melakukan observasi awal dan didapatkan bahwa pembelajaran di kelas kurang interaktif dan siswa masih takut untuk bertanya ataupun menjawab pertanyaan guru. Selain itu, guru belum menggunakan alat peraga. Pembelajaran di kelas masih menggunakan metode ceramah, tanya jawab, dan penugasan. Akibatnya, siswa kurang terlibat dalam pembelajaran dan suasana di kelas kurang menyenangkan. Suasana pembelajaran yang tidak menyenangkan mengakibatkan siswa tidak memahami materi yang disampaikan oleh guru (Choyriyyah \& Sujadi, 2014). Hal ini dapat dilihat dari prestasi belajar siswa yang rendah, yaitu $57,14 \%$ siswa masih mendapatkan nilai di bawah KKM pada saat ulangan harian.

Siklus 1 terdiri dari dua pertemuan. Pertemuan pertama dilaksanakan selama 3x40 menit dan pertemuan kedua 1 x 40 menit. Pada pertemuan pertama peneliti membahas mengenai sifat-sifat, keliling, dan luas persegi panjang. Pertemuan ini diawali dengan apersepsi, yaitu mengingatkan kembali materi garis dan sudut yang pernah dipelajari. Peneliti memotivasi siswa dengan menyampaikan tujuan dan manfaat mempelajari persegi panjang. Selanjutnya, peneliti memulai kegiatan inti dengan membagi siswa menjadi 6 kelompok heterogen. Peneliti menyampaikan materi persegi panjang menggunakan media tangram. Kemudian, peneliti membagikan LKK dan memberikan waktu untuk menyelesaikan LKK.

Selama diskusi berlangsung, peneliti berkeliling mengamati dan membimbing siswa yang mengalami kesulitan. Pada kegiatan ini sebagian besar siswa masih bertanya kepada kepada peneliti. Setelah peneliti meminta siswa bertanya, kelompok 3 menghampiri peneliti karena tidak memahami soal pada LKK. 
Hal ini dikarenakan siswa kurang teliti dalam membaca LKK. Peneliti memberikan arahan dan penjelasan kepada kelompok 3 agar kelompok dapat menyelesaikan persoalan yang ada. Selanjutnya, kelompok 2, 5, 6 mengalami kesulitan yang sama, yaitu kelompok kebingungan menentukan cara penyelesaian soal. Peneliti membimbing dan memberikan penjelasan sehingga permasalahan dapat terselesaikan dengan baik. Kemudian, diskusi berjalan lancar. Masing-masing anggota kelompok saling membantu sehingga semua soal dapat diselesaikan. Hal ini sesuai dengan pendapat Slavin (2010: 4) yang mengatakan bahwa dengan kelompok heterogen diharapkan pembelajaran lebih efektif, siswa dapat saling bekerja sama, berdiskusi, dan berargumentasi untuk mengasah kemampuan yang dimiliki dan menutup kesenjangan dalam pemahaman masing-masing.

Setelah menyelesaikan LKK, siswa mempresentasikan hasil diskusi di depan anggota kelompok lain. Siswa masih kurang percaya diri untuk presentasi di depan temannya. Peneliti memberikan arahan dan motivasi sehingga semua kelompok mempresentasikan hasil diskusinya. Selanjutnya, peneliti memberikan soal-soal tambahan menggunakan talking stick. Peneliti menyiapkan tongkat, mengatur tempat duduk dan menyampaikan langkah-langkah dan aturan talking stick. Peneliti memulai talking stick dengan memutar musik. Siswa menjalankan tongkat secara estafet dan berhenti saat musik berhenti. Siswa yang memegang tongkat terakhir harus menjawab soal. Jika siswa menjawab benar maka mendapat hadiah dari peneliti. Jika siswa menjawab salah maka soal dinyatakan gugur. Talking stick ini dilakukan selama 25 menit. Pada kegiatan ini siswa lebih aktif dan antusias mengikuti pembelajaran. Sebagai media pembelajaran, permainan memiliki beberapa manfaat, diantaranya menghilangkan stres, mengajak siswa terlibat penuh dalam pembelajaran, mencapai tujuan dengan ketidaksadaran, dan membangun kegiatan belajar yang menyenangkan (Kusuma \& Irawati, 2011). Selain itu, siswa terlihat serius dan bersungguh-sungguh mengikuti talking stick agar mendapatkan penghargaan dari peneliti. Guru harus mendesain pembelajaran yang memungkinkan siswa bersaing baik antar kelompok maupun individu untuk menambah semangat dan kesungguhan siswa dalam belajar (Suprihatin, 2015).

Pada pertemuan kedua peneliti memberikan tes akhir siklus untuk mengetahui pemahaman siswa terhadap materi yang telah dipelari. Beberapa siswa 
nampak berusaha mencontek pekerjaan temannya. Hal ini menunjukkan bahwa masih ada siswa yang kurang percaya diri terhadap kemampuannya dalam menjawab soal. Beberapa siswa masih takut salah dan mendapat nilai yang tidak memuaskan.

Pada siklus 2, kegiatan diawali dengan pembahasan mengenai sifat, keliling, dan luas jajargenjang mengacu pada hasil refleksi pada siklus 1. Berdasarkan hasil reflesi dari siklus 1, peneliti menemukan beberapa kekurangan selama pembelajaran, diantaranya (a) saat pembagian kelompok, beberapa siswa tidak mau berpindah tempat duduk sehingga mengakibatkan suasana kelas ramai; (b) saat mengerjakan LKK beberapa kelompok masih mengandalkan anggota yang pandai; (c) beberapa siswa masih kurang percaya diri untuk bertanya dan menjawab pertanyaan peneliti.

Berdasarkan hasil refleksi pada siklus 1, peneliti melakukan perbaikan pada siklus 2, dengan cara sebagai berikut; (a) pada saat pembagian kelompok peneliti meminta siswa yang disebut namanya untuk pindah menempati posisi yang ditentukan bersama kelompoknya; (2) peneliti memilih ketua kelompok untuk mengatur jalannya diskusi dan membagi tugas secara merata kepada semua anggota kelompoknya; (3) peneliti berkeliling mendatangi semua kelompok untuk menanyakan kesulitan yang ditemui pada soal.

Pada siklus 1, terdapat 70,83\% siswa tuntas belajar dan persentase hasil observasi aktivitas siswa adalah 77,08\%. Sedangkan persentase hasil observasi aktivitas guru adalah $85,41 \%$. Pada siklus 2 , siswa yang tuntas belajar mengalami peningkatan menjadi 82,61\%. Hasil analisis lembar observasi aktivitas siswa pada siklus 2 menunjukkan bahwa persentse keberhasilan aktivitas siswa sebesar 87,50\%. Sedangkan persentase observasi aktivitas guru sebesar 91,67\%.

Grafik persentase ketuntasan prestasi belajar siswa dari pra siklus, siklus 1 dan siklus 2 disajikan pada Gambar 1. 


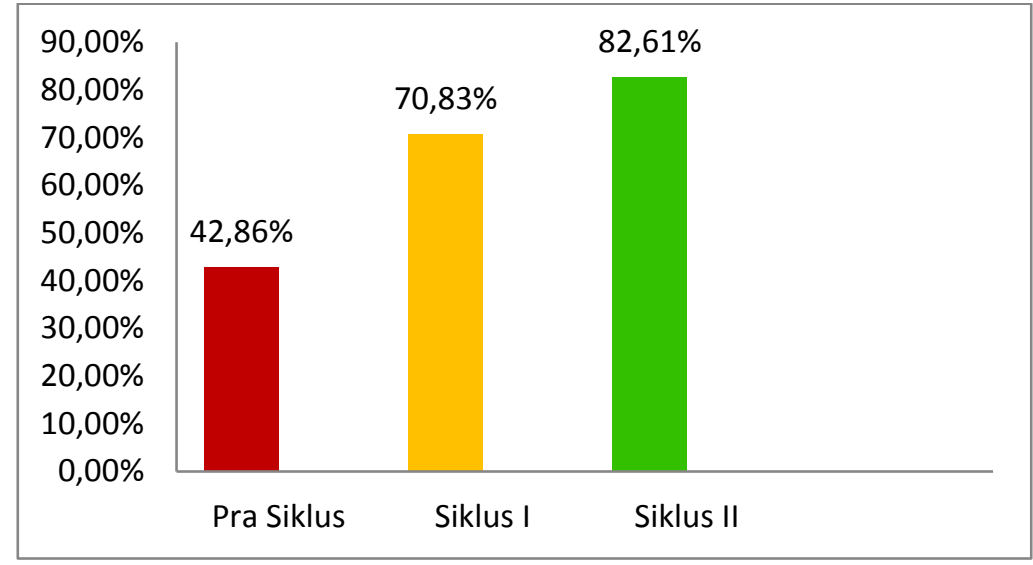

Gambar 1. Grafik Persentase Ketuntasan Prestasi Belajar Siswa

Mengacu pada Gambar 1, tampak bahwa prestasi belajar siswa meningkat dari tahap pratindakan ke siklus 1 sebesar $27,97 \%$, sedangkan peningkatan dari tahap siklus 1 ke siklus 2 sebesar 11,78\%. Hal ini berarti, pembelajaran menggunakan Talking Stick dan tangram mampu meningkatkan prestasi belajar siswa di SMP Budi Mulia Pakisaji, Malang.

\section{KESIMPULAN DAN SARAN}

Berdasarkan hasil dan pembahasan yang telah dipaparkan, disimpulkan bahwa model pembelajaran talking stick dan media tangram dapat meningkatkan prestasi belajar siswa. Mengacu pada hasil penelitian, saran bagi pembaca adalah perlu kecermatan dalam menyiapkan waktu saat kegiatan mengerjakan LKK, sebaiknya menyediakan waktu yang cukup untuk talking stick agar sebagian besar siswa mendapatkan giliran menjawab soal; Bagi peneliti berikutnya, sebaiknya tampilan media tangram lebih disempurnakan dengan ditambahkan papan khusus untuk menempel kepingan tangram, sehingga siswa lebih mudah menyusun tangram di depan kelas.

\section{REFERENSI}

Choyriyyah, M., \& Sujadi, A. A. (2014). Pembelajaran Matematika Dengan Metode Joyful Learning Dengan Media Papan Permainan Pada Materi Bilangan Bulat Kelas VII SMP Muhammadiyah Sidareja. UNION: Jurnal Pendidikan Matematika, 2(3), 265-272. 
Fataturrohmah, A., Masykur, R., \& Suherman. (2017). Pengaruh Model Cinta Berbantu Media Tangram. In Seminar Nasionall Matematika dan Pendidikan Matematika UIN Raden Intan Lampung.

Hadi, A. M. (2017). Penerapan Model Pembelajaran Geometri Di Kelas Iii Sekolah Dasar Negeri 2 Kota Bima. Aksioma, 8(1), 41-49.

Kemendikbud. (2013). Lampiran Peraturan Menteri Pendidikan dan Kebudayaan Nomor 68 Tahun 2013 tentang Kerangka Dasar dan Struktur Kurikulum Sekolah Menengah Pertama/Madrasah Tsanawiyah. Retrieved from https://urip.files.wordpress.com/2013/06/06-b-salinan-lampiranpermendikbud-no-68-tahun-2013-ttg-kurikulum-SMP-mts.pdf

Kusuma, A. I., \& Irawati, S. (2011). Pengembangan Media Pembelajaran Melalui Permainan "Hunting Treasure" Pada Materi Himpunan Untuk Siswa Kelas Bilingual VII-A di SMP Negeri 16 Malang, 1-7.

Putra, F. W., \& Wijiastuti, A. (2013). Model Pembelajaran Langsung Bermedia Tangram Terhadap Hasil Belajar Geometri Pada Anak Berkesulitan Belajar. Jurnal Pendidikan Khusus, 1-7.

Suprihatin, S. (2015). Upaya Guru Dalam Meningkatkan Motivasi Belajar Siswa, 3(1), 73-82.

Suprijono, A. (2011). Cooperatif Learning Teori dan Aplikasi PAIKEM. Yogyakarta: Pustaka Belajar. 